direct industrial sales leaves the Commission impotent to establish minimum rates in order to bring about decreased inferior industrial use. ${ }^{8 \mathrm{r}}$

It is not to be concluded that the Federal Power Commission has been ineffectual; the vigor with which the industry has sought restricting amendment of the Act denies such an inference. Nor need it be inferred that state and local regulation has no place in a comprehensive regulatory scheme, for proper control of some aspects of conservation and local distribution may depend upon familiarity with local conditions. It is not desirable, however, that the federalstate division of authority be based upon what the Supreme Court held to be the area of constitutional state action before the interstate transportation and sale of natural gas was of major importance in the economy..$^{8 z}$ Rather, the criterion of the legitimacy of federal action in the natural gas field should be whether the proposed regulation is required to protect the national interest in securing reasonable rates and an optimum utilization of the available supply of natural gas.

\title{
THE PUBLIC POLICY ASPECTS OF ADMINISTRATIVE LOBBYING CONTRACTS
}

Decisions on administrative "lobbying" contracts ${ }^{x}$ well illustrate the statement that "public policy ... is a very unruly horse, and when once you get astride it you never know where it will carry you." The recent case of Moffett $v$. Arabian American Oil Co. ${ }^{3}$ furnishes an excellent opportunity to analyse the underlying theories which lead courts to deny recovery in these cases on grounds of public policy. As a background for this discussion it will be well to consider traditional views in this field.

Courts have generally agreed that improper influence "exercised over an officer of government ..." 4 does not constitute valid consideration for a con-

${ }^{8 x}$ To some extent industrial sales on an interruptible basis are required in order to maintain high capacity utilization of pipeline facilities during periods of below peak demand and thereby reduce unit costs. The importance of high load factors may be exaggerated. FPC, op. cit. supra note ro, at $25^{8-73}$.

${ }^{82}$ Extensive interstate transportation of natural gas was not feasible before "the development of high-carbon, thin-walled steel pipes ... . and the perfection of equipment for recompressing gas in transit...." U.S. Temporary Economic Committee, Monograph 36, at 8 (1940). In r921 only 149,792 MMcf. of natural gas was transported in interstate commerce; by 1945, 1,029,758 MCMcf. passed through interstate pipelines. FPC, op. cit. supra note ro, Table 2, at 247 .

Some authorities distinguish contracts to influence administrative officials and contracts to influence legislators by applying the term "lobbying" only to the latter. Annotation, 46 A.L.R. I96 (1927). The term "lobbying" has received many definitions. See 25 Words \& Phrases 463 (1940). When it is used in this note it suggests only that two parties have agreed that, for compensation, one of them will attempt to gain action desired by the other party through legislative or administrative officials. As such, no evil connotations are intended.

2 Richardson v. Mellish, 2 Bing. 229, 252 (C.P., I824).

$38_{5}$ F. Supp. 74 (N.Y., r949).

- Oscanyan v. Arms Co., 103 U.S. 26r, 273 (1880). 
tract.s Great variation is observable, however, in the application of this principle. At least three general rules have been announced: ( $I$ ) all contracts to influence the course of administrative action are void; ${ }^{6}(2)$ all agreements which indicate a tendency to corrupt official action are void $;^{7}$ (3) corrupting acts, contemplated or actual, must be shown before recovery is denied. ${ }^{8}$ The trend has been away from the first rule, which is now practically obsolete, and toward the third, 9 indicating a greater proclivity to uphold these agreements. And, since the last two rules are commonly used to much the same effect in similar fact situations, one must finally agree that "[d]istinctions to be found in the cases on this subject do not lie in the law itself, but in its application to the particular facts."

In applying the rules courts have made distinctions in terms of the type of services and the nature of the compensation. "Legitimate" professional services are universally compensable. "Personal influence" and "personal solicitation"

s "[A]ll contracts . . . to use personal or any secret or sinister influence on legislators, [are] void by the policy of the law." Marshall v. Baltimore \& Ohio R. Co., r6 How. (U.S.) 3I4, 335 $\left(x_{53}\right)$. Courts have applied this view to administrative lobbying contracts as well as legislative. Cases cited notes $I 2$ and $I 7$ infra.

${ }^{6}$ Providence Tool Co. v. Norris, 2 Wall. (U.S.) 45,56 ( 1864 ). Immediately following this general prohibition the court explained its reasoning in such terms that future interpretation could find precedent for the tendency rule: "The law looks to the general tendency of such agreements; and it closes the door to temptation, by refusing them recognition in any of the courts of the country."

7 Hayward v. Nordberg Mfg. Co., 85 Fed. 4 (C.C.A. 6th, 1898); Bryant Lumber Co. v. Fourche River Lumber Co., I24 Ark. 313, I87 S.W. 455 (I9I6); Russell v. Courier Printing \& Publishing Co., 43 Colo. 321,95 Pac. 936 (rgo8); Stone v. Steinen Mfg. Co., 22 N.J. Misc. 353, 39 A. 2d 24 I (I944), aff'd I33 N.J.L. I6, 42 A. 2 d 268 (I945), aff'd I 33 N.J.L. 593, 45 A. 2 d 486 (r946); Crooks's Estate, 3 I6 Pa. 285, I 75 Atl. 410 (1934); Goodier v. Hamilton, I72 Wash. 60, I9 P. 2d 392 (I933); see Providence Tool Co. v. Norris, 2 Wall. (U.S.) 45 (I865); Mahoney v. Lincoln Brick Co., 304 Mich. 694, 8 N.W. $2 d 883$ (I943).

${ }^{8}$ Wyoming Ry. Co. v. Herrington, I 63 F. 2 d 1004 (C.C.A. Ioth, I947); Coyne v. Superior Incinerator Co., 80 F. 2d 844 (C.C.A. 2d, 1936); Mitchell v. Jones, IO4 Colo. 62, 88 P. 2d 557 (1939); Robert \& Co., Inc. v. Mortland, I60 Fla. I25, 33 So. 2 d 732 (I948); Cary v. Neel, 54 Ga. App. 860, I89 S.E. 575 (r936); Millspaugh v. McKnab, I34 Kan. 579, 7 P. 2 d 5 I (r932); Glass v. Swimaster Corp., 74 N.D. 282, 2I N.W. 2 d 468 (I946); Leahy v. Brooklyn Waterfront Terminal Corp., 272 App. Div. 781, 69 N.Y.S. 2d 596 (1947); Hall v. Anderson, I8 Wash. 2d 625, r40 P. 2d 266 (I943); see Spaulding v. Maillet, 57 Mont. 318, I88 Pac. 377 (1920). Accord: Cooke v. Embrey, 219 Ala. 623, x23 So. 27 (1929); Schweppe v. Sandberg, 50 Cal. App. 507, I95 Pac. 454 (I920); Grant v. Stecker \& Huff, Inc., 300 Mich. I74, I N.W. $2 \mathrm{~d} 500$ (I942). At least one court has subscribed to a rule intermediate between the tendency rule and the showing-of-corruption rule-the inherent tendency rule. Noble v. Mead-Morrison Mfg. Co., 237 Mass. 5, I29 N.E. 669 (I92I); see Valdes v. Larrinaga, 233 U.S. 705 (I9I4) (semble).

9 Compare cases cited notes 6-8 supra. Even the Supreme Court, which originally adopted the first rule in Providence Tool Co. v. Norris, 2 Wall. (U.S.) 45 (x864), has indicated a more liberal attitude in subsequent cases. See Steele v. Drummond, 275 U.S. I99 (1927).

so 16 Tenn. L. Rev. 747,748 (I94x), noting Whitley v. White, I76 Tenn. 206, I40 S.W. 2d 157 (1940).

${ }^{1 I}$ McGowan v. Parish, 237 U.S. 285 (rgI5); Stanton v. Embrey, 93 U.S. 548 (I876); Allison v. Dodge, 287 Fed. 621 (C.C.A. 3d, I923); 6 Williston, Contracts $\$$ I 729 (rev. ed. 1938 ). 
are generally condemned..$^{x 2}$ Contingent fee contracts have been held void on the ground that they afford temptation to undertake corrupting activities. ${ }^{13}$ But the more acceptable view today considers contingency of compensation as only one factor in the determination of the public policy issue. ${ }^{14}$

Various other facts have been expressly noted in the decisions. Among these are the size of the fee in relation to the services rendered ${ }^{x 5}$ and the background of the claimant-his association with public officials or his professional status. ${ }^{16}$ Nondisclosure of interest in the proposed action has also been used as a ground for denying recovery. ${ }^{x 7}$

In the light of the preceding discussion, the facts in the principal case become extremely important. King Ibn Saud of Saudi Arabia had insisted that defendant corporation provide him with $\$ 6,000,000$ per year as a loan or advance royalty payment to enable him to meet his budget requirements. Plaintiff, a former federal administrative official, longtime friend of President Roosevelt, and authority in the oil industry, agreed orally with representatives of defendant in April, I94I, to go to Washington and see if the government would assist Ibn Saud. Plaintiff saw the President and other prominent officials and claimed that as a result of his efforts Great Britain was required to undertake the payments to Ibn Saud by a condition in a loan obtained from the United States on

${ }_{12}$ Oscanyan v. Arms Co., xo3 U.S. 26x (I880); Allison v. Dodge, 287 Fed. $62 x$ (C.C.A. 3 d, I923); Hayward v. Nordberg Mfg. Co., 85 Fed. 4 (C.C.A. 6th, I898); Mahoney v. Lincoln Brick Co., 304 Mich. 694, 8 N.W. 2 d 883 (I943); Hackney v. Fairbanks, Morse \& Co., I 43 S.W. 2d 457 (Mo. App., I940); Spaulding v. Maillet, 57 Mont. 318, I88 Pac. 377 (I920); Wright v. Fissell, 92 N.J. Eq. 508, II3 Atl. 699 (I92r); Drake v. Lauer, 93 App. Div. 86, 86 N.Y. Supp. 986 (Ig04); Crooks's Estate, 3 I6 Pa. 285, I75 Atl. 4Io (I934); see Wechsler v. Novak, I57 Fla. 703, 26 So. $2 d$ 884 (1946); Noble v. Mead-Morrison Mfg. Co., 237 Mass. 5, I29 N.E. 669 (I921).

${ }^{13}$ Weehawken Realty Co. v. Hass, I3 N.J. Misc. 23I, I77 Atl. 434 (I935); Hardesty v. Dodge Mfg. Co., 89 Ind. App. I84, I54 N.E. 697 (I927); cf. Noonan v. Gilbert, 68 F. $2 d 775$ (App. D.C., I934).

${ }^{14}$ Robert \& Co., Inc. v. Mortland, I60 Fla. I25, 33 So. 2d 732 (I948); Noble v. MeadMorrison Mfg. Co., 237 Mass. 5, I29 N.E. 669 (I921); Weinstein v. Palmer, 226 Minn. 64, 32 N.W. 2d I54 (I948); Glass v. Swimaster Corp., 74 N.D. 282, 2I N.W. 2 d 468 (I946); Stone v. Steinen Mfg. Co., 22 N.J. Misc. 353, 39 A. 2d 24I (1944); Swift v. Aspell \& Co., 40 N.Y. Misc. 453,82 N.Y. Supp. 659 (I903); Hosack v. Taylor Bros., I42 Pa. Super. 83, I5 A. 2d 489 I940); Annotation, 46 A.L.R. I96, 205 (I927); 6 Williston, Contracts $\$$ I729 (rev. ed. 1938); Rest., Contracts $\S_{5} 6_{3}$ (1932); see Coyne v. Superior Incinerator Co., 80 F. $2 \mathrm{~d} 844$ (C.C.A. 2d, r936); Bradley v. American Radiator \& Standard Sanitary Corp., 6 F.R.D. 37 (N.Y., I946); Goodier v. Hamilton, I72 Wash. 60, Ig P. 2 d 392 (I933).

${ }_{x 5}$ Stone v. Steinen Mfg. Co., 22 N.J. Misc. 353, 39 A. $2 \mathrm{~d}$ 24I (I944); see Noble v. MeadMorrison Mfg. Co., 237 Mass. 5, I29 N.E. 669 (I921).

${ }^{16}$ Hardesty v. Dodge Mfg. Co., 89 Ind. App. I84, I54 N.E. 697 (I927); Davidson v. Button Corp. of America, I37 N.J. Eq. 357, 44 A. $2 d 800$ (r945); Whitley v. White, I76 Tenn. 206, I40 S.W. $2 d{ }_{157}$ (1940); cf. Hayward v. Nordberg Mfg. Co., 85 Fed. 4 (C.C.A. 6th, 1898).

${ }^{17}$ Whitley v. White, 176 Tenn. 206, I40 S.W. 2d ${ }_{57}$ (1940); Hayward v. Nordberg Mfg. Co., 85 Fed. 4 (C.C.A. 6th, I898); Crooks's Estate, 316 Pa. 285, I75 Atl. 4 10 (1934); see Noble v. Mead-Morrison Mfg. Co., 237 Mass. 5, I29 N.E. 669 (I92I). But see Cooke v. Embrey, 219 Ala. 623, I23 So. 27 (I929). 
July 2I, I94r. Defendant refused to compensate plaintiff as promised, and he sued for $\$ 6, \infty 00, \infty 00$. The jury entered a verdict awarding plaintiff $\$ x, 150,000$; the trial court set aside the verdict on motions by defendant, primarily on the ground that there was insufficient supporting evidence. Plaintiff had failed to prove that Great Britain was required, as a condition of its loan, to assume any payment to Ibn Saud or that he (plaintiff) was the efficient cause of such undertaking.

As a subsidiary ground the court held that the agreement was contrary to public policy. In resolving this issue, the court's opinion, as is often true in these cases, does not include a comprehensive analysis of the agreement and a clear explanation of how public interests were adversely affected. Our task will be to consider how the public policy issue might be treated by articulate courts which are confronted with it as the sole determinant of recovery under fact situations suggested by the principal case.

Public policy is of necessity an ambiguous and changing concept. Any attempt, therefore, to analyse cases in which it furnishes a ground for denying relief requires consideration of its pertinent components. In these cases two fundamental, and often competing, principles of policy must be consulted. The first of these is summarized by the phrase pacta sunt servanda, promises ought to be enforced. And, secondly, the public interest in good government must be considered.

In our credit economy the distinction between present and future promised possessions loses its force ${ }^{\mathrm{r}}$-a phenomenon which is reflected in the judicial enforcement of promises and the normal measure of contract damages, the value of the expectancy. But courts have also recognized that the upholding of promises must be in relation to the motive for enforcement. Since the motive is linked to business purpose, deviation of promises from the context of business agreements usually lessens the inclination to award the value of the expectancy. ${ }^{\mathrm{xg}}$ Remedial measures-reliance and restitution damages-receive sanction..$^{20}$ But when courts rule an agreement contrary to public policy no relief is obtainable. ${ }^{2 x}$ One should expect, therefore, to find courts least anxious to appeal to public policy to deny recovery where contracts adhere closest to the concept of business agreements. Later discussion will indicate that this expectation is in fact realized.22

The people's interest in good government in a democracy gives rise to con-

${ }^{88}$ Fuller and Perdue, The Reliance Interest in Contract Damages, 46 Yale L. J. 52, 373 (1936).

r9 Ibid., at 373 et seq.

${ }^{20}$ Ibid.

${ }^{21}$ Hardesty v. Dodge Mfg. Co., 89 Ind. App. 184, I54 N.E. 697 (I927); Whitley v. White, I 76 Tenn. 206, I40 S.W. $2 d$ I 57 (I940); see Providence Tool Co. v. Norris, 2 Wall. (U.S.) 45 (1865); Noble v. Mead-Morrison Mfg. Co., 237 Mass. 5, I29 N.E. 669 (I921).

22 Text at notes $38-53$ infra. 
flicting notions relevant to the enforcement of these agreements. On the one hand, citizens are interested in having their officials act only for the public good, and they desire the most efficient and economical functioning of the government. ${ }^{23}$ This consideration points toward the voiding of all agreements which would influence officials to act for private purposes. On the other hand, citizens must be free to affect official decisions. ${ }^{24}$ Administrative agencies are important purchasers in our economy. ${ }^{25}$ Some of them provide the only means of gaining a remedy $;^{26}$ others are the only source of particular types of assistance. ${ }^{27}$ All of these considerations argue for upholding the agreements.

Deciding the public policy issue in cases of administrative lobbying contracts is, therefore, a problem of evaluation. Freedom of contract, independence of official action, the interests in favor of the individual's attempt to affect official decisions, must all be considered. One other aspect of the problem ought also to be mentioned. In many of these cases there is a possibility that the defendant will be unjustly enriched if the plaintiff is denied recovery. ${ }^{28}$ Although this point is logically immaterial to the determination of the public policy issue, it might play a part in the practical solution of the cases. With these basic notions in mind, we can now consider how this process of evaluation might be carried out under fact situations similar to those in the principal case.

Certain facts appear in the court's opinion which may serve as a framework for discussion. The agreement was orally consummated and never reduced to writing; the plaintiff was selected "as a man of course expert in the field, but by and large as much if not more for his close relation with the President . . .";9 and he (plaintiff) was to "see if there was any way possible under Lend-

${ }^{23}$ See Providence Tool Co. v. Norris, 2 Wall. (U.S.) 45 (I864); Stone v. Steinen Mfg. Co., 22 N.J. Misc. 353, 39 A. 2d 24 I (I944); Cary v. Neel, 54 Ga. App. 86o, I89 S.E. 575 (I936); Annotation, 46 A.L.R. 196, 202 (I927); cf. 6 Williston, Contracts § 1727 (rev. ed. I938).

24 See Cary v. Neal, 54 Ga. App. 860, I89 S.E. 575 (I936); Schweppe v. Sandberg, 50 Cal. App. 507, 195 Pac. 454 (I920). Accord: Cooke v. Embrey, 219 Ala. 623, I23 So. 27 (Ig29).

${ }^{25}$ Consider, e.g., the War Department during the war.

${ }^{26}$ Tax boards, pardon boards and boards set up to adjudicate claims are examples. The action of these boards is tantamount to final judgment in most cases.

${ }^{27}$ Agencies charged with the issuance of charters, franchises or licenses are examples of this type.

${ }^{28}$ The unjust enrichment will probably be at the expense of the government rather than the plaintiff. Normally, therefore, courts will leave the parties as they are when a contract is found to be against public policy. A particularly striking example of this is the case of Whitley v. White, 176 Tenn. 206, 140 S.W. 2d I57 (1940), where the defendant was an agent of a limestone company and entered into an agreement with plaintiff and the vice-president of the company whereby the plaintiff was to receive $\$ 1.00$ on each ton of asphalt sold to Georgia state authorities for use on Georgia highways and defendant was to receive fifty cents on each such ton. The company had paid defendant the total sum due both plaintiff and defendant but the latter refused to turn over the plaintiff's share to him. Plaintiff was denied recovery of his share.

2985 F. Supp. I74, I8x (N.Y., I949). 
Lease or otherwise to get the government to take over the advancement of this six million dollars. . . ." $3^{\circ}$

I) Parol administrative lobbying contracts raise two problems common to all oral agreements: (a) determination of the existence of a contract, and (b) determination of what the parties were to do in accordance with the agreement. Courts normally allow the jury to resolve any issue relevant to the existence of the contract; ${ }^{3 \mathrm{I}}$ on the other hand, a jury's participation in the interpretation of the agreement is limited to cases where the court has found an ambiguity..$^{32}$ In cases involving parol administrative lobbying contracts, courts can be expected to submit issues relevant to the existence of the contract to the jury. ${ }^{33}$ But courts in these circumstances seem wont to dispose of all issues relevant to the meaning of the agreement without assistance from the jury. ${ }^{34} \mathrm{It}$ is probable that these courts are considering the conditions surrounding the making of the agreement, 35 the object of the agreement, ${ }^{36}$ and the subsequent acts of the plaintiff, ${ }^{37}$ as indicative of the terms and meaning. This type of procedure is undoubtedly necessary, except in those clear cases where professional services alone appear. Personal influence and personal solicitation may simply be a means of bringing a meritorious claim before the only parties who can satisfy it; on the other hand, they may be a means of gaining action which is without merit. The difficulty of drawing the line is obvious. Because many of the agreements do not indicate on their face in which category plaintiff's services fall, recourse must be had to evidence which will enable the court to resolve the issue on the basis of probabili-

${ }^{30}$ Ibid., at 177 .

${ }^{3 x} 3$ Williston, Contracts $\$ 616$, at I 774 n. 5 (rev. ed. 1938 ).

${ }^{32} 3$ Williston, Contracts $\$ 616$ (rev, ed. I938).

33 The court in the principal case followed this procedure.

${ }^{34} \mathrm{~A}$ few courts have sanctioned the submission of such issues to the jury. See Allison v. Dodge, 287 Fed. 62I (C.C.A. 3d, I923); Noble v. Mead-Morrison Mfg. Co., 237 Mass. 5, I29 N.E. 669 (I92I); Cooke v. Embrey, 219 Ala. 623, I23 So. 27 (I929). Nevertheless, the common practice seems as stated. The court in the principal case followed the normal procedure. There was no reference to the meaning of the agreement relevant to the public policy issue in the charge to the jury; the issue was resolved exclusively by the court in setting aside the verdict.

${ }_{35}$ The court in the principal case followed this procedure in its opinion. $85 \mathrm{~F}$. Supp. $\times 74$, I80-8I (N.Y., I949).

${ }^{36}$ Text at notes $38-53$ infra.

37 The court in the principal case stated that it was "considering the contract alone." 85 F. Supp. I74, at I80 (N.Y., I949). Other courts have indicated the same. Drake v. Lauer, 93 App. Div. 86, 86 N.X. Supp. 986 (I904); cf. Gesellschaft fur Drahtlose Telegraphie M.B.H. v. Brown, 78 F. 2 d 4 IO (App. D.C., I935). In practice, however, courts generally consider the subsequent acts of the plaintiff as indicative of the terms of the agreement and their meaning. See Crooks's Estate, $316 \mathrm{~Pa}$. 285, I75, Atl. 4 ro (I934); J. E. Hanger, Inc. v. Fitzsimmons, 273 Fed. 348 (App. D.C., I92I); Hayward v. Nordberg Mfg. Co., 85 Fed. 4 (C.C.A. 6th, I898). The very statement of the rule requiring a showing of corrupting acts, contemplated or actual, would indicate that the courts which adopt such a rule will not hesitate to consider the performance as well as the agreement. 
ties. It is submitted, however, that in any case where this evidence indicates a possibility of reasonable differences in conclusions about the type of acts contemplated or performed under the agreement, the court ought to submit the issue to the jury.

2) It is generally stated that personal influence or personal solicitation vitiates administrative lobbying agreements. ${ }^{8} \mathrm{By}$ this courts presumably mean the type of influence or solicitation which may gain official action irrespective of the merits of the proposal. In practice, courts have allowed recovery where a claimant has been retained, at least in part, because of his personal influence and his services consisted of personal solicitation which might have resulted in official action without reference to the merits of the proposed action. 39 The case of Coyne v. Superior Incinerator $\mathrm{Co}^{40}$ is an extreme example. Because of his business and political connections, plaintiff's assignor was employed by defendant on a contingent fee basis to sell incinerator plants to two municipalities. $4^{\mathrm{I}}$ The Court of Appeals for the Second Circuit reversed the district court's holding that the agreement was against public policy. It held that the mere possibility of corrupting acts was not enough to disallow recovery, saying: "There must be proof that something contrary to good morals was contemplated or done." ${ }_{42}$

The Coyne case not only shows that courts do allow recovery in some cases where overwhelming personal influence appears as a possible factor; it also indicates the type of case in which courts are most likely to require actual proof of corrupting acts- where the agreement is to seek a sales contract. The argument in Swift v. Aspell \& Co.43 exemplifies the attitude:

A person having something to sell has the right to sell it through an agent, and this right is an incident to his ownership. To declare that he may not employ an agent, upon commission, where the government is the prospective buyer, is to take away what is ordinarily one of the elements of the enjoyment of ownership-the unrestricted right to sell. Upon this line of reasoning, commission agreements for a sale to the government have been upheld and enforced in this State where the agreement did not actively require corruption in its performance. 44

The distinction between agreements to secure sales contracts and other types of administrative lobbying agreements reflects the evaluative process involved in the decision of these cases. Sales contracts and salesmen are normal in the

${ }^{38}$ Cases cited note 12 supra.

${ }^{39}$ Robert \& Co., Inc. v. Mortland, I60 Fla. I25, 33 So. $2 d 732$ (x948); J. E. Hanger, Inc. v. Fitzsimmons, 273 Fed. $34^{8}$ (App. D.C., I92I); Allison v. Dodge, 287 Fed. 621 (C.C.A. 3 d, 1923) (jury question).

4080 F. $2 d 844$ (C.C.A. 2 d, I936).

${ }_{4}$ In both of the municipalities the contracts were made only after competitive bidding. In one of the towns, defendant's bid was lowest; in the other, the highest.

$$
\begin{aligned}
& 4380 \text { F. } 2 \text { d } 844,847 \text { (C.C.A. } 2 \text { d, r936). } \\
& 4340 \text { N.Y. Misc. } 453,82 \text { N.Y. Supp. } 659 \text { (rgo3). } \quad 44 \text { Ibid., at } 454,660 .
\end{aligned}
$$


business community.45 On the other hand, many of the non-sales purposes are peculiar to the government and depend entirely on the discretion of public officials. ${ }^{4}$ As divergence from the normal business type of agreement increases, courts become less inclined to favor recoveries and more cognizant of the importance of independent official action. Contracts to secure claim settlements, 47 reductions in taxes, ${ }^{48}$ franchises, ${ }^{49}$ charters, ${ }^{50}$ and pardons, ${ }^{51}$ are examples. The emphasis shifts. Plaintiffs can recover only if they bring themselves within the category of "legitimate" professional services, which in effect means that the facts must not indicate the possibility of overwhelming personal influence or solicitation.

An analogy is suggested-that between legislative lobbying and non-sales

15 In J. E. Hanger, Inc. v. Fitzsimmons, 273 Fed. 348 (App. D.C., I92I), the court denied defendant's contention that the contract was contrary to public policy and said: "The only influence contemplated by the contract was the proper influence of a salesman." Ibid., at $35 \mathrm{I}$.

${ }^{6}$ The New York Court of Appeals stated the distinction in these terms: "The decision in Norris v. The Tool Co. (2 Wall. 45), confounds a sale or traffic openly made by an avowed agent to a party wishing to purchase, with the forbidden case of an interference with legislative action or executive clemency, where the party does not profess to act upon commercial principles. There is a manifest difference in the principle governing the cases." Lyon v. Mitchell, 36 N.Y. 235, 242-3 (I867). Though the early Supreme Court and federal court decisions in this field indicate that sales lobbying contracts ought to be treated in accordance with the same principles as legislative lobbying contracts (see Hazelton v. Sheckels, 202 U.S. 7 I [rgo6]; Hayward v. Nordberg Mfg. Co., 85 Fed. 4 [C.C.A. 6th, I898]), the general trend has been toward the view expressed in the Lyon case. Accord: 6 Williston, Contracts $\$ 1729 \mathrm{~A}$ (rev. ed. I938); see Whitley v. White, I76 Tenn. 206, I40 S.W. $2 \mathrm{~d}$ ×57 (I940).

${ }^{77}$ Early Supreme Court decisions upheld contracts where plaintiffs were hired to represent defendants by appearing before boards set up to adjudicate claims. Their activities were encompassed within the term "professional" services. Wright v. Tebbitts, 9I U.S. 252 (I875); Taylor v. Bemiss, I Io U.S. 42 (I884); see Hazelton v. Schekells, 202 U.S. 7 I (Igo6). However, where such boards were not in being and legislation had not yet established the basis for the claim, recovery has been denied. Gesellschaft Fur Drahtlose Telegraphie M.B.H. v. Brown, 78 F. $2 d$ 4Io (App. D.C., r935). Where a plaintiff has simply argued the claim on the merits and has not used any influence which might preclude independent official decisions, there is little doubt that he may recover. See McGowan v. Parish, 237 U.S. 285 (Igr5).

${ }^{4}$ See Weehawken Realty Co. v. Hass, I3 N.J. Misc. 23I, I77 Atl. 434 (I935). The better view today, however, holds that where plaintiff is an accountant or lawyer who was retained to argue for the reduction before the tax board, recovery is obtainable, irrespective of the type of compensation. Hosack v. Taylor Bros., I42 Pa. Super. 83, I $_{5}$ A. $2 d 489$ (r940) (contingent compensation); Feist \& Feist, Inc. v. Hurley, 120 N.J.L. 522, I A. 2 d 24 (1938) (distinguished from the Weehawken case on the grounds that suit here was on a quantum meruit theory); cf. Weinstein v. Palmer, 226 Minn. 64, 32 N.W. 2d I54 (I948).

${ }^{49}$ Two Supreme Court decisions indicate a proclivity to uphold these contracts where personal solicitation does not appear from the facts. See Steele v. Drummond, 275 U.S. 199 (I927); Valdes v. Larrinaga, 233 U.S. 705 (I914).

so Bryant Lumber Co. v. Fourche Lumber Co., r24 Ark. 313, I87 S.W. 455 (rgr6); cf. Goodier v. Hamilton, I72 Wash. 60, I9 P. 2d 392 (I933).

51 Spaulding v. Maillet, 57 Mont. 3I8, 188 Pac. 377 (I920). The distinction in the Restatement between "[a] bargain to procure a pardon or to solicit by personal influence the granting of a pardon ..." which is illegal, and "a bargain to prepare a petition for a pardon and to make an argument in support of it before the pardoning power ...," which is not illegal, seems sound. Rest., Contracts $\$ 56 \mathrm{I}$; see 6 Williston, Contracts $\$$ I73I (rev. ed. I938). 
administrative lobbying contracts..$^{2}$ In both cases officials are empowered to bestow or withhold benefits which are not measured in material returns-goods or services. In supervising and controlling sales contracts various measures may be used. The goods and services may have a market value or contracts may be consummated only after competitive bidding. Accounting techniques provide some means of comparing the expenditures and value received. On the other hand, there is no easy means of controlling or supervising either legislative or non-sales administrative action. While the lack of knowledge of the matters up for consideration is not so prevalent among administrative officials who may gain "expertise" through long experience, the interests of the people depend, in both fields, almost entirely on the integrity and knowledge of their officials. This observation does not indicate that these officials need be corrupt. It indicates simply that overwhelming personal influence and personal solicitation are more likely to be the subjects of contracts in these fields. For this reason, plus the fact that these contracts do not exhibit a business motive, ${ }^{53}$ courts are more willing to deny recovery than in cases involving agreements to obtain sales contracts.

In the principal case the plaintiff was chosen for the agreement because of his friendship with many high government officials, particularly the President. ${ }^{4}$ In accordance with the preceding analysis, it is important to determine the object of the agreement-whether for a sales contract or other administrative action. It is clear from the case that no,sales contract was desired. Plaintiff was to seek assistance for defendant. It is conceivable that such assistance may have been in terms of a gift, as the plaintiff's claim that Great Britain was to assume payment of the required amounts to Ibn Saud would imply, or in terms of a loan, as an advance by lend-lease, secured by future royalty payments would indicate.

3) If Great Britain was in fact required, by a condition in its loan from the United States, to pay Ibn Saud, then defendant would have been completely relieved of its obligation to the king at a savings of $\$ 6,000,000$ per year.s5 Plaintiff, then, would be seeking compensation for obtaining a gift for the defendant from the government, and, unless he could show more than mere personal influ-

52 See note 46 supra.

53 Text at notes $43-5$ I supra.

si Plaintiff had evidently recovered $\$ 25,000$ from Standard Oil Company of California for out-of-pocket expenses for activities carried on in behalf of that corporation while he was serving as Federal Housing Administrator in 1934 and $x 935$. N.Y. Times, p. 35, col. 6 (Feb. 4, 1949). In his letter to the corporation asking payment plaintiff said: "As a matter of fact, while I was in Washington, I was really doing more work and was in a much more helpful position for the Standard Oil Company than if I had remained in the office at 30 Rockefeller Plaza. ..." Defendant's brief at Ix.

ss There is no indication in the court's opinion, the briefs of plaintiff or defendant, or in the charge to the jury, whether it was claimed that Britain was to loan Ibn Saud the money or make a gift to him. In any event, it does not seem precise to say that defendant would be saved $\$ 6,000,000$ per year. If defendant had paid the money it would have been on a loan basis, secured by future royalty payments. But the securing of this sum might have been difficult for defendant at the time, and failure might have cost defendant its oil rights in Saudi Arabia. 
ence as a basis for his claim against defendant, it is clear that he would fail. The danger of the granting of the gift on the basis of friendship rather than merit would be convincing.

Before considering the possibility that plaintiff was to secure a loan for defendant, it may be well to examine an aspect often overlooked in these cases. One would expect that the dictates of the legislature and of administrative agencies would be carefully weighed in determining the public policy issue. The difficulty, however, is that there are few statutes or administrative regulations on the subject.56 Moreover, courts have exhibited a tendency to apply these precepts narrowly, precluding analogical reasoning. ${ }^{57}$ Unless the statute or regulation specifically makes certain types of contracts void, courts are likely to interpret it as having no relevance for public policy..$^{8}$ It appears that the true task which courts ought to undertake is the determination of whether the statute or regulation is meant to establish criteria of public policy, or whether it is simply designed to save the government money. ${ }^{59}$

${ }^{56}$ The statutes are generally declaratory. See Spaulding v. Maillet, 57 Mont. 3I8, I88 Pac. 377 (1920); notes 58-59 infra.

57 This tendency of courts in general to narrowly construe statutes has long been noted and condemned. Pound, Common Law and Legislation, 21 Harv. L. Rev. 383 (Ig08).

${ }^{8}$ Courts occasionally speak of statutes and regulations as prime sources of public policy. Bradley v. American Radiator \& Standard Sanitary Corp., 6 F.R.D. 37 (N.Y., I946); see Steele v. Drummond, 275 U.S. $x_{99}$ (1927). In practice, however, appeals to these sources to vitiate agreements which would otherwise be valid are rare. For example, Executive Order 900r, 6 Fed. Reg. 6787,6788 (r94r), promulgated under the First War Powers Act, 55 Stat. 839 (I94I), on December 29, I94I, required that every contract entered into by a contractor with the War Department, Navy Department, or United States Maritime Commission contain the following clause: "The contractor warrants that he has not employed any person to solicit or secure this contract upon any agreement for a commission, percentage, brokerage, or contingent fee. Breach of this warranty shall give the Government the right to annul the contract, or, in its discretion, to deduct from the contract price or consideration the amount of such commission, percentage, brokerage, or contingent fees. This warranty shall not apply to commissions payable by contractors upon contracts or sales secured or made through bona fide established commercial or selling agencies maintained by the contractor for the purpose of securing business."

A good argument can be made that the regulation merely indicated that the government was interested in entering agreements at minimum cost. Considering the time of the orderthe first few weeks of the war - federal courts held that the regulation established a rule of public policy and interpreted it as distinguishing agents regularly employed, who may recover (Reynolds v. Goodwin-Hill Corp., I54 F. 2d 553 [C.C.A. 2d, I946]), from agents not regularly employed, who are denied recovery. Bradley v. American Radiator $\&$ Standard Sanitary Corp., 6 F.R.D. 37 (N.Y., 1946), aff'd I59 F. 2 d, 39 (C.C.A. 2d, I947). State courts, on the other hand, have held the regulation irrelevant in the determination of the public policy issue (Leahy v. Brooklyn Waterfront Terminal Corp., 272 App. Div. 78I, 69 N.Y.S. 2d 596 [I947]; Hall v. Anderson, 18 Wash. 2d 625 I40 P. 2d 266 [1943]) or they have interpreted it as simply declaratory of prior existing criteria of public policy. Ebeling v. Swaine Mfg. Co., 357 Mo. 549, 209 S.W. 2d 892 (1948); Bradford v. Durkee Marine Prod. Corp., x80 N.Y. Misc. 1049, 40 N.Y.S. 2d 448 (1943); Singer v. Bruner-Ritter, Inc., I80 N.Y. Misc. 928, 42 N.Y.S. 2d 88I (r943); but see Glass v. Swimaster Corp., 74 N.D. 282, 2I N.W. 2d 468 (I946).

${ }^{59}$ See note 58 supra. Courts have not yet approached the problem from this angle. In I 946 Congress passed the Federal Regulation of Lobbying Act. 60 Stat. 839,2 U.S.C.A. $\$ \S 26 \mathrm{r}-270$ (Supp. I948). The prime purpose of this act was to cause lobbyists to register. Though highly 
Assuming that the plaintiff in the principal case was to obtain assistance from the government in terms of lend-lease aid to Ibn Saud, secured by future royalty rights on the oil taken from Saudi-Arabia, the analogy to a loan is apparent. The policy with respect to the making of loans by federal agencies was expressed in the Emergency Relief and Construction Act of 1932 (R.F.C. Act):

No fee or commission shall be paid by any applicant for a loan under the provisions of this section in connection with any such application or any loan made or to be made under this section, and the agreement to pay or payment of any such fee or commission shall be unlawful.60

And, the Reconstruction Finance Corporation regulation pertinent to loans to private industry provides:

Charges, commissions, bonuses, fees, etc. Payment of bonuses, fees, or commissions for the purpose of, or in connection with, obtaining loans is strictly prohibited. However, the business enterprise, subject to the prior approval of the Corporation, may be allowed to pay the actual reasonable costs incurred in the making of the loan. Such charges may include reasonable compensation for services rendered by attorneys, appraisers, accountants, etc., but not in any event for alleged services in connection with the presentation of the application to the Corporation. . . . Fees or charges contingent upon the obtaining of a loan will not be allowed. . . . ${ }^{6}$

Courts have generally followed the rules set out in the statute and regulation in cases where the loan was obtained from the Reconstruction Finance Corporation. ${ }^{62}$ There is no reason, however, why these precepts should be applied so narrowly. They indicate a desire to assure the granting of loans on the basis of the merits of the application. Prima facie, therefore, they signify criteria of public policy. To apply these criteria to contracts to affect the action of another government agency ${ }^{6}$ charged with the task of administering loans requires no long step. Moreover, the distinction between foreign and domestic loans presents no barrier to the application of the criteria. Actually, the loan in this case would be for the benefit of a domestic corporation, although the money would go directly from lend-lease to Ibn Saud. Under this type of analysis, plaintiff would

ineffective (see Improving the Legislative Process: Federal Regulation of Lobbying, 56 Yale L. J. 304 [r947]), the act indicated that Congress sanctioned a view expressed in some cases (cf. cases cited note 17 supra) that secrecy-withholding of knowledge of interest from officials is anathema. Despite the fact that the act applied in terms to legislative lobbying, there is no inherent reason why this should not be taken as a criterion of public policy in administrative lobbying contracts, especially in non-sales contract cases. No decisions have been found, however, which even consider the act in respect to legislative lobbying.

${ }^{6}$ Section 20r(i), 47 Stat. 709, 7 r3 (I932), repealed 6r Stat. 208 (1947) (emphasis added).

${ }^{6 x} 4$ Code Fed. Reg., Tit. 13, § I3.II (r939).

60 No recovery allowed: Hardt v. Heller Bros. Co., 72 F. Supp. 795 (Pa., I947); Chatterton v. Waverly Terminal Co., 49 F. Supp. 545 (N.J., I943). Recovery allowed: Wyoming Ry. Co. v. Herrington, 163 F. 2 d 1004 (C.C.A. Ioth, 1947 ).

${ }^{6}$ The office of lend-lease Administrator was established by Executive Order in r94I. 6 Fed. Reg. 55Ig. 
be required to bring himself within the exceptions to the rules or else be denied relief.

One further aspect of the principal case remains for consideration. Plaintiff might have attempted to show that his suggestions were for the public good as well as for defendant's benefit. Courts generally deny the materiality of such an argument, insisting that such services would be lawful only if no compensation were expected. ${ }^{64}$ Plaintiff, however, might argue against the application of the general rule on two grounds: (I) questions of foreign oil policy form an exception to the rule; (2) the rule is an erroneous interpretation of the judicial function in denying recovery on grounds of public policy.

Plaintiff might contend, and with a valid basis, that our foreign oil policy with respect to the Middle East has been, in effect, the policy of the oil companies interested in this area. ${ }^{65} \mathrm{It}$ is no doubt true that appeals to the President and administrative officials to protect the interests of these companies have not been unusual.66 Plaintiff's argument would then be that individuals who are retained by these companies to present their proposals to government officials should not be denied recovery because of personal influence or solicitation. It seems certain that no court would be convinced by such an argument. Whether or not the oil companies do in fact dictate oil policy in the Middle East ought to be immaterial to the determination of plaintiff's right to recover. The oil companies are not charged with the duty of protecting the public interest; they hold no official position. It may be that the United States has not adopted a policy independent of that proposed by the oil companies. This does not mean that officials ought to act any less independently in ascertaining the interests of the United States. Permitting recovery under such circumstances may be even more dangerous than in the ordinary case since public officials who are customarily subjected to private solicitations are the ones most apt to lose sight of the public interest.

The plaintiff might also argue that, while a denial of recovery on grounds of public policy implies that the proposed action was injurious to the public welfare, he might in fact have been able to demonstrate that such action would have been beneficial to the nation as a whole. Considering the German interest in the Middle Eastern oil fields at the time of the agreement-April, I94I-and the imminent danger of German conquest of the whole area, the interests of the United States, cognizant of its own possible implication in the war, would prob-

${ }^{64}$ The court in the principal case argued somewhat in this manner. See 85 F. Supp. I74, r8x (N.Y., r949); cf. Johnson v. Board of Comm'rs, x92 N.C. 56 r, I35 S.E. 6r8 (r926).

${ }_{65} \mathrm{Neal}$, The Petroleum of the Middle East 43 (I947).

60 "American companies, or companies with a part American interest, have obtained concessions in Iran, Afghanistan, India, Syria, Palestine, Egypt and Qatar. While no direct diplomatic intervention has been called for, these companies have kept the Department [of State] informed of their progress, and the Department's good offices have been used many times in straightening out minor difficulties which these companies were experiencing." Ozanne, U.S. Foreign Oil Policy I4 (II World Oil Series, I945). 
ably best be served by friendship with Ibn Saud. Granting this, the general rule denying the materiality of such an argument seems appropriate. ${ }^{67}$ Courts are not competent to investigate the merits of particular proposals. Courts appeal to public policy to deny recovery where officials might be moved by overwhelming personal influence or personal solicitation to act in a way in which, upon independent judgment, they would not act. When a party seeks compensation for his services, it is clear that public benefit was not his only motive. Any public benefit is coincidental as far as he is concerned. The argument which denies recovery where no public benefit appears remains just as sound where it does.

This discussion has encompassed an analysis of factors which might be considered by a court in determining whether a party ought to be relieved from promissory liability on grounds of public policy under fact situations suggested by the principal case. Needless to say, there is no absolute answer to be given as to how a court should act in these circumstances. Certain general observations can be made. Courts ought to be articulate as to their reasons for denying recovery. Where the evidence indicates a possibility of reasonable differences in conclusions about the type of acts contemplated or done under the agreement, the court ought to submit the issue to the jury. Courts ought to recognize that they are carrying on an evaluative process, and they should use statutes and administrative regulations, directly or by analogy, where these sources indicate criteria of public policy.

\section{TAXATION OF FAMILY PARTNERSHIP INCOME- THE TOWER DOCTRINE REINTERPRETED}

The problem of correlating tax incidence to various intra-family financial transactions has long been a stumbling block in federal income tax law. The family partnership involved in the recent case of Comm'r v. Culbertson ${ }^{\mathrm{x}}$ again brought this correlation problem before the Supreme Court. Except as to trusts, ${ }^{2}$ the Internal Revenue Code sheds little light on the problem, and the courts have been compelled to rely on the broad language of Section 22(a), ${ }^{3}$ defining gross income, as their only guide. In putting content into Section 22(a) the courts have evolved three basic principles applicable to these transactions.

67 See note 64 supra.

${ }^{x} 337$ U.S. 733 (I949).

${ }^{2}$ Int. Rev. Code $\$ \$ 166,167,26$ U.S.C.A. $\$ \$ 166,167$ (1945), assess the tax to the grantor when power to revest the corpus rests in him or in a person not having a substantial adverse interest to him, or where the income of the trust is applied to the benefit of the grantor. These provisions, while of help, did not solve all the problems of the family trust. See text at note II.

3 Int. Rev. Code \$ 22(a), 26 U.S.C.A. \& 22(a) (I948). The provision reads (in part): " "Gross income' includes gains, profits, and income derived from salaries, wages, or compensation for personal services ... of whatever kind and in whatever form paid, or from professions, vocations, trades, businesses, commerce, or sales, or dealings in property, whether real or personal growing out of the ownership or use of an interest in such property; also from interest, rent, dividends, securities, or the transaction of any business carried on for gain or profit, or gains or profits and income derived from any source whatever. ..."? 